\title{
A PERSONAGEM HERÓI INFANTOJUVENIL NA CONTÍSTICA DE MIA COUTO SOB A PERSPECTIVA DOS ESTUDOS NARRATIVOS ${ }^{1}$
}

Flavio García

RESUMO: Em alguns dos contos de Mia Couto, há personagens protagonistas figuradas como crianças a caminho da adolescência, que, por suas virtudes éticas e psicológicas, são compostas com valor positivo em termos axiológicos, sociais ou morais, e suas ações, excepcionais e muitas vezes difíceis de entender, resultam em triunfo sobre o caminho acidentado da narrativa. No universo dos estudos narrativos, essas personagens protagonistas são reconhecidas como heróis, destacando-se de demais personagens e, mesmo, de quaisquer outras coprotagonistas que possam surgir no texto. Tal fenômeno composicional se dá, por exemplo, em "O dia em que explodiu o Mabata Bata", de Vozes anoitecidas, "O embondeiro que sonhava pássaros", de Cada homem é uma raça, "Nas águas do tempo", de Estórias abensonhadas, "O menino que escrevia versos", de $O$ fio das missangas, e $O$ pátio das sombras.

PALAVRAS-CHAVE: figuração de personagem, personagem herói, infantojuvenil, sonho, contística.

ABSTRACT: In some Mia Couto's short stories, there are protagonists characters figured as children on their way to adolescence, who, due to their virtues in ethical and psychological terms, are composed with positive value in axiological, social or moral terms, and their actions, exceptional and often difficult to understand, result in triumph over the rugged path of the narrative. In the universe of narrative studies, these protagonist characters are recognized as heroes, standing out from other characters and even from any other co-protagonists that may appear in the text. Such compositional phenomenon occurs, for example, in "O dia em que explodiu o Mabata Bata", by Vozes anoitecidas, "O embondeiro que sonhava pássaros", by Cada homem é uma raça, "Nas águas do tempo", by Estórias abensonhadas, "O menino que escrevia versos", by 0 fio das missangas, and $O$ pátio das sombras.

KEYWORDS: character figuration, hero character, juvenile, dream, short stories.

1 Título em língua estrangeira: "The juvenile hero character in Mia Couto's short stories from the perspective of narrative studies" 
O objetivo central deste ensaio é observar diferentes processos de composição que intervêm na figuração de personagens de contos do escritor moçambicano Mia Couto, os quais podem ser reconhecidos como protagonistas e, a partir desse reconhecimento, heróis. O percurso de leitura desses contos segue os estudos narrativos, "um campo de investigação e de ensino centrado na teoria e na análise da narrativa, com fundamentos epistemológicos e metodológicos na narratologia, tal como ela se constituiu a partir dos anos 70 do século XX" (REIS, 2018, p. 119). Assim, tendo em vista que Carlos Reis $^{2}$ é o estudioso que vem desenvolvendo as teorias acerca da figuração e autor do Dicionário de estudos narrativos (REIS, 2018), em que reúne ampla diversidade de concepções teórico-conceituais advindas de fontes variadas, opto por percorrer os procedimentos narratológicos a partir dos verbetes de seu dicionário.

As reflexões teóricas, metodológicas, conceituais e críticas que se dão no universo dos estudos da narrativa pressupõem o texto que thes provocam e/ou sobre o qual se elaboram. Portanto, o relato observado em si é essencial a toda e qualquer abordagem que dele se pretenda fazer, não sendo plausível, em hipótese alguma, abdicar da história, ou seja, "dos acontecimentos e personagens" (REIS, 2018, p. 196)

2 https://coimbra.academia.edu/CarlosReis 
que a povoam, nem do discurso, o "modo como o narrador dá a conhecer [a história] ao leitor" (REIS, 2018, p. 196).

Na perspectiva dos estudos narrativos, "[o] conceito de personagem pode ser definido [...] como a representação de uma figura humana ou humanizada que, numa ação narrativa, contribui para o desenvolvimento da história e para a ilustração de sentidos projetados por essa história" (REIS, 2018, p. 388). Tratarei, contudo, apenas da personagem humana, embora haja algumas figuras humanizadas bastante importantes na obra de Mia Couto.

Ainda conforme os estudos narrativos:

O herói é a figura central de um relato, implicando-se nele valoração positiva da personagem, em termos axiológicos, sociais ou morais. Trata-se, então, de um protagonista qualificado, que se salienta do conjunto das restantes personagens por ações excecionais, muitas vezes difíceis de entender ou de igualar. (REIS, 2018, p. 193)

Essa "superioridade do herói resulta normalmente num triunfo que culmina um percurso acidentado" (REIS, 2018, p. 194), portanto, sua atuação é essencial à ultrapassagem dos acontecimentos adversos que se interpõem na narrativa, implicando, geralmente, mas nem sempre, a vitória do bem sobre o mal. A despeito disso, centrar-me-ei somente nas situações em que o bem sobrepuja o possível mal. 
A delimitação do que seja a figura do herói infantojuvenil é o aspecto conceitual mais celeumático - e de certo modo controverso - do recorte que assumo, uma vez que se imiscui no quadro das literaturas infantil, juvenil e, especialmente, infantojuvenil, que envolve aspectos da produção e da recepção. Concedo-me, todavia, a liberdade de não transitar por esse continente minado e delimitar o que entendo por infantojuvenil, tendo em conta a figuração dessas personagens.

Segundo Carlos Reis, "A figuração designa um processo ou um conjunto de processos discursivos e metaficcionais que individualizam figuras antropomórficas, localizadas em universos diegéticos específicos, com cujos integrantes aquelas figuras interagem, enquanto personagens" (REIS, 2018 , p. 165). Ele observa, no entanto, que "[a] manifestação mais evidente da entidade designada como figura é a personagem" (REIS, 2018, p. 162).

Na concepção de Reis:

A figuração é dinâmica, gradual, complexa, significando isto três coisas: primeira, que normalmente ela não se esgota num lugar específico do texto; segunda, que ela se vai elaborando e completando ao longo da narrativa; terceira, que, por [...] sua natureza dinâmica, a figuração não se restringe a uma descrição de personagem, nem mesmo 
a uma caracterização, embora esta possa ser entendida como seu componente importante. Assim, a figuração deve ser encarada como um macrodispositivo mais amplo, englobante e consequente do que a caracterização. (2018, p. 166)

Nesse sentido, estou elegendo como personagem herói infantojuvenil figuras cuja descrição corresponda ao imaginário que percebo que a sociedade tem de indivíduos em fase de desenvolvimento da infância em direção à adolescência, sem perder de vista que essa seja uma suposição empírica de minha parte, e admito, entretanto, que vou enfrentar adversidades, pois a questão não é pacífica. Assumo, ainda assim, a opção de prosseguir, pois nunca haverá, nem há de haver, consensos em estudos dessa ordem.

Na acepção que ora me interessa, os estudos narrativos definem a descrição como sendo "um procedimento imitativo em que se procura representar as características de uma figura, [...] sobretudo no tocante aos seus componentes físicos, mas também, eventualmente, incidindo sobre outros componentes (psicológicos, culturais, simbólicos, etc.)" (REIS, 2108, p. 76). Não indicarei, passo a passo, os processos de composição empregados por Mia Couto na figuração das personagens heróis infantojuvenis que elegi. Pretendo destacar sua presença ao longo da narrativa. 
Esses processos de composição envolvem a nomeação da personagem, com explicitação de seu nome e/ou sobrenome; a utilização de alcunha ou apelido - que não são exatamente a mesma coisa -; o emprego de qualificativos de ordem variada; referências a aspectos sociais, culturais, religiosos, psicológicos, afetivos etc.; ações exercidas ou sofridas. Enfim, a figuração de uma personagem comporta um amplo conjunto de procedimentos discursivo-textuais.

Tendo-me imposto uma leitura cronológica da obra de Mia Couto, foi impossível não começar estas reflexões acerca das personagens heróis infantojuvenis por Azarias, o miúdo de "O dia em que explodiu o Mabata Bata", de Vozes anoitecidas, seu primeiro livro de contos, publicado em 1986. Logo a seguir, veio Tiago, de "O embondeiro que sonhava pássaros", de Cada homem é uma raça, de 1990. Adiante, vieram duas personagens heróis infantojuvenis inominadas, a primeira delas de "Nas águas do tempo", de Estórias abensonhadas, de 1994, e a segunda de "O menino que escrevia versos", de O fio das missangas, de 2004. Por fim, ainda sobreveio o herói de O pátio das sombras, de 2009.

Essa escolha das personagens heróis infantojuvenis foi, obviamente, arbitrária, pois se subordinou às minhas 
leituras subjetivas, feitas sob as perspectivas teóricas, metodológicas e críticas que adotei. Somente quando cheguei a esses heróis, dei-me conta de que não havia entre eles nenhuma personagem herói feminina. Admito que ainda preciso refletir acerca disso para, somente então, tentar entender qual teria sido a razão de tal fato, se falha minha, como leitor desatento, ou fenômeno próprio à obra de Mia Couto.

Azarias era um menino órfão em decorrência da guerra civil - que alguns chamam de guerra de desestabilização -, ocorrida após a independência de Moçambique. Ele era criado pela avó Carolina e pelo tio Raul, para quem trabalhava, acordando ainda de madrugada e levando os bois do tio para a pastagem. Sua vida se resumia a ser maltratado e cuidar dos bois. "Os filhos dos outros tinham direito da escola. Ele não, não era filho" (COUTO, 1997, p. 49), mas ir à escola era um sonho do menino, que ele não podia realizar: "O serviço arrancava-o cedo da cama e devolvia-o ao sono quando dentro dele já não havia resto de infância. Brincar era só com os animais." (COUTO, 1997, p. 49). Mabata Bata, anunciado no título, era o maior e mais bonito de todos os bois, prometido por Raul como dote de casamento à família da noiva. Azarias gostava de nadar no rio montado no Mabata Bata. 
Um dia, sem explicação, "o boi explodiu" (COUTO, 1997, p. 47), sua carne e seus ossos se espalharam pelo ar, e "os chifres ficaram num qualquer ramo, balouçando a imitar a vida, invisível do vento" (p. 47). O menino buscou explicações. Acontecera "a desgraça: o boi poeirado, eco de silêncio, sombra de nada" (p. 47). O pobrezinho ainda pensou "Deve ser foi um relâmpago?" (p. 47). Como prestaria contas ao tio Raul, pois "relâmpago não podia ser. O céu estava liso, azul, sem mancha. De onde saíra o raio? Ou foi a terra que relampejou?" (COUTO, 1997, p. 48), perguntava-se, interrogando "o horizonte, por cima das árvores" (p. 48).

Sem encontrar respostas plausíveis, ele recorreu às crenças telúricas e pensou no ndlati, "a ave do relâmpago" (COUTO, 1997, p. 48), que, provavelmente, "ainda rodasse os céus" (p. 48). O ndlati teria se lançado sobre o chão, em um voo incendiado, fazendo um buraco e deixado sua urina. Azarias imaginou que "talvez o Mabata Bata pisara uma réstia maligna do ndlati. Mas quem podia acreditar?" (p. 48).

Sendo o dote de casamento do tio, Azarias tinha certeza de que ele não aceitaria tal explicação. "Havia de querer ver o boi falecido, ao menos ser apresentado uma prova do desastre" (COUTO, 1997, p. 48), porque "bois relampejados: ficavam queimados, cinzas arrumadas a lembrar o corpo. 0 
fogo mastiga, não engole de uma só vez, conforme sucedeu$\mathrm{se}^{\prime \prime}$ (p. 48). O menino lembrou-se das ameaças do tio: "Não apareças sem um boi, Azarias. Só digo: é melhor nem apareceres" (COUTO, 1997, p. 49).

A única solução era fugir. Ninguém queria "saber da sua alma pequenina, dos seus sonhos maltratados" (COUTO, 1997, p. 49). Vivia sem esperanças de futuro. Olhou sem pena para o campo que ia deixar e "[p]artiu na direcção do rio. Quando chegou ao rio, atravessou a fronteira da água. Na outra margem parou à espera nem sabia de quê" (COUTO, 1997, p. 49).

A tarde chegou ao fim, e o menino não retornou com os bois. A avó ficou preocupada, lembrando-se de que havia bandidos à solta. Aflita, falou com Raul, que atribuiu o atraso a malandragens. "De repente, alguém bateu à porta" (COUTO, 1997, p. 50). Eram três soldados que vinham "comunicar o acontecimento: rebentou uma mina esta tarde. Foi um boi que pisou. Agora, esse boi pertencia daqui" (p. 50). Os soldados queriam saber onde estava o pastor que cuidava dos bois. "Os bandidos andaram espalhar minas nesse lado" (p. 50), disseram.

Desesperado e destemperado, Raul não ouviu as ponderações da avó Carolina e partiu à procura do menino e dos bois. Meteu-se noite adentro, gritou por Azarias. Ordenou-lhe que voltasse. Mas "[s]ó o rio respondia, 
desenterrando a sua voz corredeira" (COUTO, 1997, p. 51). Ele "adivinhava a presença oculta do sobrinho" (p. 51) e jurava não lhe bater, mentindo, pois "ia matar-lhe de porrada, quando acabasse de juntar os bois" (p. 51). Ouviu barulhos na outra margem, e pensou que era o menino, mas "não era. Chegou-Ihe a voz de Carolina" (p. 51), que, preocupada, viera procurar o neto.

Raul mandou que ela voltasse para casa, pois temia que pisasse em alguma mina e estourasse pelos ares. A avó sabia que o menino, se vivo estivesse, estaria morrendo de medo e não confiaria no tio. Ele somente confiaria nela, que "aplicou sua confiança, chamando" (COUTO, 1997, p. 52). Em resposta ao chamado, "[p]or trás das sombras, uma silhueta deu aparecimento" (p. 52).

A avó Carolina perguntou como Azarias estava e Ihe pediu para ajudar o "tio a juntar os animais", (COUTO, 1997, p. 52) suplicando para que ele voltasse com ela. O tio ameaçou bater-Ihe até Ihe quebrar todo, quis saber dos bois, se estavam juntos, como estavam, onde estavam. Azarias disse que os bois estavam reunidos, que não havia que os recolher. Mas "o tio não estava certo da verdade do Azarias" (COUTO, 1997, p. 53) e insistiu na pergunta: “- Sobrinho: fizeste mesmo? Juntaste os bois?" (p. 53). 
A avó acreditava absolutamente que fosse verdade, pensou no fim da briga entre os dois e que o tio estaria muito satisfeito, que Ihe daria um prêmio, bastava que ele escolhesse o pedido. "Raul achou melhor concordar com tudo, naquele momento. Depois, emendaria as ilusões do rapaz e voltariam as obrigações do serviço das pastagens" (p. 53).

O tio mandou que Azarias falasse logo o que queria. "- Tio: próximo ano posso ir na escola?" (COUTO, 1997, p. 53). Raul sabia que permitir seria "ficar sem guia para os bois. Mas o momento pedia fingimento" (p. 53). Respondeu: "- Vais, vais" (p. 53). O menino, descrente, duvidou: “- É verdade, tio?" (p. 53). Raul respondeu: “- Quantas bocas tenho, afinal?". (p. 53) Azarias demonstrou boa fé: "- Posso continuar ajudar nos bois. A escola só frequentamos da parte da tarde" (COUTO, 1997, p. 53). E o tio fingiu concordar com tudo. Acreditando na promessa, "O pequeno pastor saiu da sombra e correu o areal onde o rio dava passagem. De súbito, deflagrou um clarão, parecia meio-dia da noite" (COUTO, 1997, p. 53).

Azarias "engoliu aquele todo vermelho, era o grito do fogo estourando. Nas migalhas da noite viu descer o ndlati, a ave do relâmpago" (COUTO, 1997, p. 53-54). Ele ainda "Quis gritar: - Vens pousar quem, ndlati? Mas nada não 
falou" (COUTO, 1997, p. 54). Tudo à volta eram sons, cores, fumos, suicídio. Teria falado ou pensado: "-Vens pousar a avó, coitada, tão boa? Ou preferes o tio, afinal das contas, arrependido e prometente como o pai verdadeiro que morreu-me?" (p. 54).

A morte simbólica, antes decidida e adiada pela intervenção da avó com a falsa promessa do tio em realizar o desejo, foi concretizada com a morte física, pois "antes que a ave do fogo se decidisse Azarias correu e abraçou-a na viagem da sua chama" (COUTO, 1997, p. 54). Era pássaro? Relâmpago? Mina? Fora escolha? Acidente? Acaso? Foi o fim para Azarias, personagem herói infantojuvenil, cujos valores denotam uma superioridade excepcional, entregando-se à morte para salvar sua avó e seu tio, com ações senão difíceis de entender, impossíveis de igualar.

Azarias é figurado como um menino negro, filho de naturais da terra, e os procedimentos que demarcam sua composição se baseiam em referenciais próprios a esse seu mundo. Tiago, de "O embondeiro que sonhava pássaros", diferentemente de Azarias, é figurado como um menino branco, filho de colonos portugueses. Esses processos composicionais determinam Azarias como um miúdo 
submisso e Tiago, transgressor. Mas ambos desempenham a função de personagem herói infantojuvenil, sofrem interdições e enfrentam a morte com entornos de mistério. Tiago é o coprotagonista de uma história na qual, um velho negro, vendedor de pássaros, "o passarinheiro", desencadeia os acidentes do percurso narrativo. O espaço em que se desenrola a história de "O dia em que explodiu o Mabata Bata" se limita ao campo, reservado aos da terra, já em "O embondeiro que sonhava pássaros", as ações transitam entre o campo e o bairro de cimento, espaço privilegiado dos colonos.

Todas as manhãs, o passarinheiro vinha à cidade, descalço, exibir pássaros tão belos, nunca antes vistos pelos colonos, que chegavam a pressupor que ele tivesse acesso a outros mundos, de onde tirasse esses pássaros. O negro passava em frente às casas com os passarinhos cantando e encantando as crianças, que acorriam para ver. Os colonos se sentiam ofendidos e externavam sentimentos de racismo e preconceito em relação ao velho e, extensivamente, aos negros da terra como um todo.

Tiago, filho de colonos portugueses, não se importava com o que seus pais Ihe diziam. Desobedecia-lhes. Eles mandavam que mantivesse distância do negro. Mas ele 
descia as escadas da casa, chegava-se ao passarinheiro e o seguia até o campo, permanecendo fora durante todo o dia. Quando voltava, já à noite, o pai queria explicações de onde estivera. A mãe, porém, sublimava as atitudes do menino. Um dia, o pai quis saber se o negro tinha casa, onde morava. Tiago respondeu que ele morava em um embondeiro. Embebido das crenças locais, falou da importância da árvore sagrada, contou lendas que aprendeu.

Prenuncia-se, nessa passagem, sob o ponto de vista da figuração da personagem, uma simbiose entre Tiago, o branco filho de colonos portugueses, e o passarinheiro, negro natural da terra.

Os colonos se sentiam afrontados com a presença do negro descalço, que encantava as crianças e exibia pássaros tão exuberantes. Assim, proibiram as crianças de irem até ele e, quando ele passava, fechavam as janelas, as cortinas, trancavam-se todos.

Nessa passagem da narrativa, o espaço ganhou vida e se manifestou, coisas estranhas aconteceram. Cortinas, janelas, portas, armários, gaiolas se abriram sozinhas. Surgiram alpiste e bosta de passarinho por todos os cantos. Os colonos atribuíram os acontecimentos ao vendedor de pássaros e se reuniram na casa de Tiago para decidir o que fariam com ele. 
Pressupondo a sentença porvir, o menino, que, fingindo dormir, ouvira tudo por detrás da porta, correu para avisar ao velho. O negro o escutou, pegou uma roupa típica dos brancos, se vestiu e se pôsa esperar, passiva e pacificamente. Tiago perguntou por que ele estava se vestindo assim e insistiu para que fugisse. Mas ele disse que já sabia que aquilo iria acontecer e que se vestia assim para receber os outros. Ele "era natural, rebento daquela terra. Devia de saber receber os visitantes. Lhe competia o respeito, deveres de anfitrião" (COUTO, 2009, p. 73).

Pediu que Tiago voltasse para casa, mas o menino não se dobrou. Olhou para uma grande flor, para o embondeiro, relembrou as lendas que ouviu e ainda tentou conversar com o velho. Mas colonos vinham chegando, e Tiago se escondeu. Eles pegaram o negro e começaram a espancá-lo, tirando-lhe sangue. Amarram-no e o arrastaram pelo caminho. $O$ menino, escondido, assistiu a tudo. Nesse momento, "as flores do embondeiro tombaram, pareciam astros de feltro. No chão, suas pétalas brancas, uma a uma, se avermelharam" (COUTO, 2009, p. 73).

O passarinheiro foi levado para o calabouço, onde ordenaram que o guarda o interrogasse, o espremesse bem e retirasse toda a verdade. "Mas nem ele sabia que segredos devia arrancar do velho" (COUTO, 2009, p. 74). 
Tiago não voltara para casa. Seguiu em direção à prisão. Escondeu-se detrás do muro. Hesitou entre rezar ou não.

Sozinho com o guarda, o negro pediu licença para tocar uma música, uma música da terra do colono. Ao tentar tocar, disfarçou e disse que não está conseguindo, porque Ihe teriam machucado muito a boca. Jogou a gaita pela janela. Ela caiu “junto do esconderijo de Tiago" (COUTO, 2009, p. 74), que a apanhou, rejuntou-a e, como num sonho, começou a tocar na expectativa de que "o passarinheiro escutasse aquele conforto" (COUTO, 2009, p. 75). Logo, muitos pássaros, muitos cantos, todo o céu coberto. Tiago entrou na prisão e procurou o passarinheiro, gritou por ele, mas nem sinal. Somente os pássaros responderam.

O menino, então, "[d]ecidiu voltar à árvore. Outro paradeiro para ele já não existia. Nem rua nem casa: só o ventre do embondeiro" (COUTO, 2009, p. 75). Os passarinhos o seguiram, cantando. À volta do embondeiro, as pétalas deixaram de ser vermelhas e voltaram a ser brancas. Não havia nenhum sinal do negro. Tiago se aconchegou dentro do embondeiro, ficou à espera, tocando a gaita, e nem se deu conta das vozes que se aproximavam. Os colonos pensaram que era o negro que estava lá dentro e incendiaram o tronco do embondeiro. Mas quem estava lá dentro era o menino, que: 
Transitava de reino: arvorejado. E do sonâmbulo embondeiro subiam as mãos do passarinheiro. Tocavam as flores, nasciam espantosos pássaros. Foi quando Tiago sentiu a ferida das labaredas, a sedução das cinzas. Então, o menino, aprendiz da seiva, se emigrou integrou para suas recentes raízes. (COUTO, 2009, p. 76)

Aquela simbiose de Tiago, menino branco, filho de colonos portugueses, com o passarinheiro, velho negro, natural da terra, prenunciada quando ele contou as lendas e defendeu as crenças locais a seus pais, é consumada no final da narrativa. E se podem recuperar algumas das perguntas feitas no final de "O dia em que explodiu o Mabata Bata", em relação ao que aconteceu a Azarias. Foi escolha de Tiago, acidente, acaso? Há que se substituir, no entanto, a afirmação que segue àquela sequência de perguntas por mais uma indagação. Foi o fim para Tiago, ou um recomeço?

Azarias, de "O dia em que explodiu o Mabata Bata", e Tiago, de "O embondeiro que sonhava pássaros", são personagens heróis infantojuvenis cujas ações, no desfecho da história, implicam sua entrega à morte. No percurso das narrativas, ainda que Azarias seja obediente e submisso, e Tiago, desobediente e subversor, ambos apresentam sobrevalores éticos, morais, sociais, psicológicos, religiosos, e suas ações são excepcionais. 
A personagem herói infantojuvenil de "Nas águas do tempo", identificado somente por neto, está na lembrança da personagem-narrador, pai de um menino que buscou refazer, com seu filho, o mesmo que o avô fizera consigo.

Todos os dias, o avô o punha num barquinho e desciam rio abaixo. A mãe ficava preocupada, queria saber aonde iriam, o que iam fazer. Mas o velho sorria e nunca respondia. O menino também nunca o sabia. Voltavam ao mesmo lugar e nada faziam de concreto. No percurso, o avô lhe ensinava crenças da terra, como não contrariar os espíritos, respeitar o sentido da corrente da água. De repente, estancava e deixava o barquinho sonolento. "O avô, calado, espiava as longínquas margens" (COUTO, 2009a, p. 14). Ficavam quietos, como se estivessem rezando. O avô "[t] irava seu pano vermelho e agitava-o com decisão" (p. 14). O neto queria saber "[a] quem acenava ele" (p. 14), porque não via nada. E o avô Ihe perguntava: "- Você não vê lá, na margem? Por trás do cacimbo?" (p. 14). Mas ele não via, e o avô insistia: “- Não é lá. É láááá’. Não vê o pano branco, a dançar-se?" (COUTO, 2009a, p. 15). O menino só via neblinas.

Ao chegaram a casa, a mãe reclamava, ralhava, depois amolecia e ainda brincava, falando de lendas da terra. "Ao 
menos vissem o mamweixo moba! Ainda ganhávamos vantagem de uma boa sorte" (p. 15). Era a crença de um "fantasma que surgia à noite, feito só de metades: um olho, uma perna um braço" (p. 15). O avô comentou que quando jovem o viu uma vez, mas a mãe disse que era invencionice. A meninada queria ver, tinha lá suas curiosidades sobre o tal fantasma.

Um dia, quando o barco parou, o neto ficou curioso e quis descer. O avô ficou muito bravo. "- Nunca! Nunca faça isso!" (COUTO, 2009a, p. 16). O menino se desculpou. O avô explicou que "- Neste lugar, não há pedacitos. Todo o tempo, a partir daqui, são eternidades" (COUTO, 2009a, p. 16). O neto já estava com um pé dentro e outro fora do barco e, sem achar apoio, desequilibrou-se. $\mathrm{O}$ avô tentou ajudar, mas o barco virou e caíram na água. Ficaram "lutando dentro do lago, agarrados às abas da canoa" (p. 16). O avô pegou o pano e começou a agitá-lo sobre a cabeça, mandando que o neto fizesse o mesmo. O menino, mesmo não vendo ninguém, obedeceu e fez. O redemoinho das águas se tranquilizou, eles deixaram de ser puxados para baixo, puderam desvirar o barco e subir nele novamente. Voltaram para casa em silêncio. Chegando, quando amarravam o barco, o avô lhe pediu para não contar nada à mãe. 
Naquela noite, o velho Ihe revelou um segredo:

Nós temos olhos que se abrem para dentro, esses que usamos para ver os sonhos. O que acontece, meu filho, é que quase todos estão cegos, deixaram de ver esses outros que nos visitam. Os outros? Sim, esses que nos acenam da outra margem. E assim lhes causamos uma total tristeza. Eu levo-Ihe lá nos pântanos para que você aprenda a ver. Não posso ser o último a ser visitado pelos panos. (COUTO, 2009a, p. 17)

Na tarde seguinte, o avô o pôs no barquinho, desceu rio abaixo, repetiu o mesmo ritual. Só que, nesse dia, o sol começou a se pôr e o avô procurava e parecia não ver nada, ninguém. De repente, mandou que o neto ficasse no barco e desceu. O menino se assustou. "O avô pisava os interditos territórios" (COUTO, 2009a, p. 17).

Ele avistou o avô avançando e sumindo na neblina. Sentiu um arrepio de frio e viu "uma garça de enorme brancura atravessar o céu. Parecia uma seta trespassando os flancos da tarde, fazendo sangrar todo o firmamento" (COUTO, 2009a, p. 18). Então, entendeu o segredo contado pelo avô na noite anterior. Vislumbrou "na margem, do outro lado do mundo, o pano branco. [...] Enquanto ainda duvidava foi surgindo, mesmo ao lado da aparição, o pano vermelho [do avô, e distinguiu] o pano dele se branquejando" (p. 18). 
O percurso heroico dessa personagem infantojuvenil se encontra na coragem cega que empreende a cada dia no passeio rio abaixo, na cumplicidade assumida com o avô, e na assunção do sonho que o avô lhe transmite. No desfecho da narrativa, fica-se sabendo que esse neto inominado descobriu em si "um rio que nunca haveria de morrer" (COUTO, 2009a, p. 18), ao qual ele volta com seu filho "Ihe ensinando a vislumbrar os brancos panos da outra margem" (p. 18). Daí que os ancestrais só morrem de todo se são esquecidos. Se não, permanecem vivos na memória.

Mantendo-me fiel à cronologia das publicações, seria natural que eu passasse de "Nas águas do tempo", de Estórias abensonhadas, para "O menino que escrevia versos", de $O$ fio das missangas, mas me vou valer dos processos de composição da personagem herói infantojuvenil de "Nas águas do tempo", um neto, e de sua temática, a cumplicidade e o não esquecimento dos mortos, envoltos pelo o sonho do ancestral, para ir a 0 pátio das sombras, em que se verificam muitas semelhantes.

Esse livro de Mia Couto inaugurou, em 2009, a coleção Contos e Histórias de Moçambique, projeto da Escola Portuguesa de Moçambique em parceria com a Fundação Contos para o Mundo de Barcelona. A coleção, com dez 
títulos, foi inspirada em uma mensagem de Nelson Mandela, reproduzida na contracapa de todos os volumes, desejando que a voz do narrador de contos nunca morresse em África e que as crianças nunca perdessem a capacidade de ampliar os seus horizontes do mundo com a magia dos relatos. A partir de 2015, os mesmos dez livros da coleção moçambicana foram lançados no Brasil pela Editora Kapulana, encerrando, em 2019, com O pátio das sombras, vencedor do Prêmio da Fundação Nacional do Livro Infantil e Juvenil de 2019 - Produção 2018 - (Categoria: Literatura em Língua Portuguesa).

Os livros da coleção são compostos pela reescrita de contos ou lendas da tradição oral, feita por ficcionistas moçambicanos, com ilustração de artistas plásticos também do país. Após a nova história, tem-se o texto inspirador original e, a seguir, uma breve explicação do ficcionista sobre sua escolha, com comentários sobre seu processo de reescritura. Ao fim, encontram-se informações biográficas do ficcionista e do ilustrador.

O pátio das sombras, conforme Mia Couto esclarece em seu paratexto, baseou-se em um conto maconde "muito sugestivo" (COUTO, 2009b, p. 27), levando-se em conta que, "quando lembrados, os mortos nunca chegam a morrer" 
(p. 27). Segundo ele, a narrativa que tomou por base "se enquadra[ria] na crença generalizada nas sociedades rurais [de] que as mulheres viúvas e velhas se convertem em feiticeiras." (p. 27). Teria sido "esta a razão que leva[ria] a mulher idosa a ser morta, no final da história" (COUTO, 2009b, p. 27), mas ele, por entender que se devam questionar esses valores, altera o desfecho narrativo em sua nova história, "do ponto de vista da ética que o conto sugere" (p. 27), com a intervenção da personagem herói infantojuvenil, ausente no texto inspirador original. Mia Couto diz que "seria bom criar um clima de mistério e introduzir um núcleo de conflito que se adensaria para, no final, se resolver de forma positiva" (p. 27).

No conto maconde, a história se passa em "uma pequena aldeia, [na qual] havia uma mulher que sepultava os filhos dentro da cabeça dela à medida que iam morrendo. Quando entravam em sua cabeça, ficavam vivos" (COUTO, 2009b, p. 23). Assim, a cabeça da mulher começou a ficar muito grande e a pesar tanto que "[e]la não podia mais sair de casa" ( $p$. 23). Um dia, a cabeça estourou, saíram os filhos renascidos, e festejaram com comidas, danças e cânticos.

Os que estavam no campo ouviram os festejos e acorreram à aldeia, mas os filhos da mulher retornaram 
à sua cabeça sem serem vistos. No outro dia, os aldeões tramaram deixar um deles à espreita. Aconteceu o mesmo que na véspera. Ao voltarem, o espia contou o que viu. No outro dia, muitos ficaram de vigia, e, novamente, o mesmo se repetiu. A velha acabou posta em uma jaula e foi morta. Os espíritos dos filhos não puderam mais voltar para dentro da cabeça de sua mãe. Mortos e vivos misturaram-se, "[e] as aldeias encheram-se de gente, enchendo-se de alegrias" (COUTO, 2009b, p. 25).

Em $O$ pátio das sombras, a velha, cujos filhos mortos são sepultados na cabeça, é identificada como avó; há um poço e uma pulseira; um dos netos e seu pai, já morto, atuam no percurso e desfecho narrativos. Como no conto maconde, a velha não pode ir à colheita porque lhe dói a cabeça. O neto quer ficar com ela, mas ela o manda ir. Antes que ele vá, ela percebeu que ele está usando uma pulseira, perguntou-lhe onde a pegou e a pede de volta. Ele disse que a encontrou perto da fogueira. Ela contou-Ihe que pertencera a seu pai, já morto. Ele se arrepiou e entregou-lhe a pulseira.

Todos foram para a colheita e, do campo, estranharam "ruídos de festa [que] vinham lá da aldeia" (COUTO, 2009b, p. 7). Mandaram que o neto voltasse para averiguar. "Já perto de casa, o menino viu vultos mas não mais do que isso: 
sombras, ruídos, risos e fugitivas sombras, escaparem-se entre as árvores da floresta" (p. 7). Chegando, "[e]ncontrou a avó junto ao poço" (p. 7). Disse-lhe que o mandaram para ver o que se passava, porque escutaram vozes e risos vindos da aldeia, e ele mesmo teria sentido barulhos, ouvido tambores.

A avó nega, dizendo estar só, porém, demonstra-se atrapalhada. "Os olhos dela cravaram-se nos dele a pedir confirmação. Então, pediu ao menino que lançasse uma pedra dentro do poço" (COUTO, 2009b, p. 8). Ele perguntouIhe se é para ver se ainda tinha água. "Ela não respondeu. Pegou na pedra e atirou para dentro da boca escura do chão. Lá do fundo respondeu um lamento" (COUTO, 2009b, p. 8). A avó quis saber se ele ouviu. Assustado, ele perguntou o que era o barulho que ouvira. A avó disse-Ihe que era "a água chorando" (COUTO, 2009b, p. 10).

No dia seguinte, "o trabalho da colheita foi [novamente] interrompido por ruídos provenientes da aldeia. Uma vez mais, o menino foi enviado para esclarecer o que estava sucedendo" (COUTO, 2009b, p. 11). No percurso, ele chocouse com um homem que vinha na direção oposta. Tombou ao chão. Ficou aturdido. Algo caiu próximo ao seu rosto. Era a mesma pulseira que devolvera à avó. Com medo, pegou-a e escondeu-a às pressas. 
A avó veio em seu socorro. Ele disse-lhe que caíra porque se chocara com um homem que corria em direção oposta à dele. Ela afirmou ser impossível, pois estava só. Ele pegou a pulseira e perguntou-lhe o que seria aquilo. A avó quis saber de onde ele a retira. Ele disse que caíra do tal homem. Ela insinuou que ele estivesse mentindo. Ofendido e incapaz de argumentar, ele se afastou e se dirigiu ao poço, pois a avó sempre lhe dissera que ali, junto à água, era um bom lugar para chorar. Chorou, e suas lágrimas caíram dentro do poço. Um doce lamento ecoou, parecendo-lhe dizer: - Não chore, meu filho!

A avó, então, veio até ele, sentou-se ao seu lado e contou que os filhos mortos moravam vivos dentro da sua cabeça, e, à medida que iam morrendo, a cabeça começava a tornar-se muito grande. Era essa a razão de não mais poder ir à colheita. E, quando ficava só na aldeia, os filhos saíam de sua cabeça e festejavam. Entre os filhos revividos que lhe saíam da cabeça estava o pai do menino. Ela pediu-Ihe segredo, e ele, em troca, que tornasse a ver o pai. Ela concordou.

No dia posterior, quando todos iam para o campo, ela chamou o neto para ficar com ela, e todos concordaram. Ela o pôs junto de si e, de mãos dadas, cantou canções de ninar. 
Ele adormeceu, sonhou, e o sonho abriu-lhe contato com o mundo anímico da ancestralidade, encontrando-se com o pai, que the pediu a pulseira de volta. Ele negou, alegando que, se a devolvesse, o pai jamais regressaria. Mas o pai riu e disse-lhe que o que fazia não era regressar, porque nunca saíra dali. Explicou-Ihe que "[o]s mortos não morrem quando saem da Vida. Morrem quando são esquecidos" (COUTO, 2019b, p. 18).

O desfecho de $O$ pátio das sombras tem um tom de fábula. A personagem herói infantojuvenil entendeu que "o sonho era o modo como os falecidos visitavam os vivos e festejavam a Vida. E desde esse dia, sempre que ele queria, dançava e cantava com seu pai nesse infinito pátio que se chama 'sonho'" (COUTO, 2019b, p. 19).

Tal como o neto de "Nas águas do tempo", esse neto de O pátio das sombras aprende com seu ancestral a manter os mortos vivos na memória, revisitando-os; a valorizar e respeitar os sonhos que Ihe são transmitidos, lá, pelo avô, aqui, pela avó. De certa maneira, esses dois netos driblam a morte. Considerando-se o conto maconde que Mia Couto tomou por base para a escritura de sua nova história, a inserção dessa personagem é essencial para sobrepujar a morte no desfecho da história. 
"O menino que escrevia versos" tem início com a mãe da personagem herói infantojuvenil fazendo uma espécie de denúncia a um médico: "- Ele escreve versos!" (COUTO, 2009c, p. 131). O médico, em réplica, quer saber se "- Há antecedentes na família?" (p. 131). A mãe não entende a pergunta.

A sequência efabulativa é entrecortada, e a história descamba para a figuração do "pai da criança, mecânico de nascença e preguiçoso por destino, nunca espreitara uma página" (COUTO, 2009c, p. 131). Em meio a esse processo, fala-se da relação entre a mãe e o pai, circunstanciando as condições em que o menino foi gerado, nasceu e cresceu, com dificuldades. "Tudo corria sem mais, a oficina mal dava para o pão e para a escoa do miúdo. Mas eis que começaram a aparecer, pelos recantos da casa, papeis rabiscados com versos" (p. 131). Essas aparições se interpõem à realidade que vivem e provocam dúvidas. Contudo, "O filho confessou, sem pestanejo, a autoria do feito: - São meus versos sim!" (COUTO, 2009c, p. 132).

O pai não se agradou daquilo. "[H]avia que tirar o miúdo da escola. Aquilo era coisa de estudos a mais, perigosos contágios, más companhias" (COUTO, 2009c, p. 132). Disse que "em vez de se lançar no esfrega-esfrega com as meninas, se acabrunhava nas penumbras, e, pior ainda, escrevia 
versos" (p. 132). Para ele, tratava-se mariquice da criança. A mãe "defendeu o filho e os estudos. O pai, conformado, exigiu: então ele fosse examinado" (p. 132). A situação era vista pelo pai como uma "vergonha familiar" (p. 132). Que fosse ao médico, e o medico visse o havia de erro, de falha, de falta. Não se importava em pagar.

O médico, depois de ouvir tudo, "[a]viava já a receita para poupança de tempo" (COUTO, 2009c, p. 132), quando se dirigiu ao menino e lhe perguntou "- Dói-te alguma coisa?" (p. 132). O menino respondeu que "- Dói-me a vida, doutor" (p. 132). O médico ficou surpreso. A mãe ainda quis fazer com que o médico visse isso como demonstração da doença. Mas o médico olhou para menino e perguntou: “- E o que fazes quando te assaltam essas dores?" (p. 132). O menino respondeu que fazia o que melhor sabia fazer, sonhar.

A mãe deu-lhe um tabefe na nuca e perguntou se ele não se lembrava do que o pai tinha dito sobre sonhos. O menino e a mãe falaram sobre o assunto. Quando o menino começou a explicar a questão do sonho, "O doutor o interrompeu: Não tenho tempo, moço, isto aqui não é nenhuma clínica psiquiátrica" (COUTO, 2009c, p. 133). Mas a mãe insistiu e pediu que o médico ao menos visse os cadernos do menino, os versos, motivo de tão grave distúrbio. Ainda que 
contrafeito, o doutor disse para que deixasse, que ele veria depois, e que voltassem na semana seguinte.

"Na semana seguinte, foram os últimos a ser atendidos" (COUTO, 2009c, p. 133). O médico quis saber se o menino continuava a escrever, se tinha mais versos. De início, o menino não entendeu, e o médico voltou à pergunta. Em resposta, o menino disse "- Isto que faço não é escrever, doutor. Estou, sim, a viver. Tenho este pedaço de vida - disse, apontando um novo caderninho - quase a meio" (p. 133).

"O médico chamou a mãe, à parte. Que aquilo era mais grave do que se poderia pensar. O menino carecia de internamento urgente" (p. 133). A mãe, aos prantos, disse que a família não tinha como pagar. Mas o médico respondeu que não importava, ele mesmo assumiria as despesas. A internação seria ali mesmo em sua clínica. E assim se fez.

A partir daí, quem lá vai "raramente encontra o médico" (COUTO, 2009C, p. 134). Ele fica manhãs e tardes sentado no quarto do menino, e "Quem passa pode escutar a voz pausada do filho do mecânico que vai lendo, verso a verso, o seu próprio coração" (COUTO, 2009c, p. 134), enquanto o médico Ihe diz "Não pare, meu filho. Continue lendo..." (p. 134).

O sonho, enquanto ideia, ilusão, devaneio, desejo, busca de felicidade que move o ser humano, participa da figuração 
de todas essas personagens heróis infantojuvenis como elemento essencial aos seus processos de composição. É o sonho que as faz desempenhar a função "de [...] protagonista qualificado, que se salienta do conjunto das restantes personagens" (REIS, 2108, p. 193), mesmo de coprotagonistas. E, porque sonham, ancoradas em valores axiológica, social, moral, ética e psicologicamente positivos, suas ações, excepcionais e muitas vezes difíceis de entender, pois implicam, em várias situações, sua própria morte, resultam no triunfo final sobre o percurso acidentado da narrativa.

Azarias sonhava em ir à escola, e sua ação derradeira é o sonho de salvar a avó e o tio do ndlati, entregando-se à própria morte. Tiago, ao lado do passarinheiro, sonhava com as lendas da terra, às quais acabou por se entregar no desfecho, morrendo fisicamente dentro do tronco do embondeiro em brasas. Os netos de "Nas águas do tempo" e O pátio das sombras aprenderam o sonho de manter os mortos vivos na memória e driblaram a morte, seja simbolicamente, como no caso do avô a ser visto do outro lado do rio, seja concretamente, como no caso da avó que, diferentemente da velha do conto maconde, escapa à morte. A personagem protagonista de "O menino que escrevia 
versos" abriu os sonhos do seu coração para a vida e fez o médico sonhar com ele. De uma maneira geral, todos esses meninos enfrentaram, no emaranhado sociofamiliar em que viviam, semelhantes ritos de passagem, termo-conceito “popularizado pelo antropólogo alemão Arnold van Gennep no início do século $\mathrm{XX}^{\prime \prime}{ }^{3}$.

Pode-se afirmar que, como a infância e a adolescência não são percebidas na África sob o mesmo prisma que são pela visão burguesa eurocêntrica, eles não chegam a representar, na totalidade, seres em fases de infâncias efetivas, distanciados dos problemas do universo adulto, como se pensava que devesse ser quando do surgimento de uma concepção de infância tradicional. Sua composição implica uma figuração que imiscui valores situados entre a ótica estrangeiras e a realidade das tradições e dos costumes africanos. Trata-se de "[r]itos de passagem [...] que marcam momentos importantes na vida"4, como o devir adulto se manifestando na criança que deveriam ser, experienciando um amadurecimento de certo modo imposto pelas situações vividas.

Todavia, seja em África, seja qualquer outra parte do planeta, em:

3 https://pt.wikipedia.org/wiki/Rito de passagem. Acesso em: 7 fev. 2021.

4 https://pt.wikipedia.org/wiki/Rito de passagem. Acesso em: 7 fev. 2021. 
Todas as sociedades, determinados momentos na vida de seus membros são marcados por cerimônias especiais, conhecidas como ritos de iniciação ou de passagem. Essas cerimônias, mais do que representar uma transição particular para o indivíduo, representa igualmente a sua progressiva aceitação e participação na sociedade na qual estava inserido, tendo, portanto tanto o cunho individual quanto o coletivo. ${ }^{5}$

Todas essas personagens envolveram-se com o sonho, aprenderam a sonhar, demonstraram valores éticos, morais, sociais, psicológicos e religiosos demasiadamente bem valorados, tendo exercido ações excepcionais que, em boa medida, são difíceis de serem igualadas por outras personagens das mesmas narrativas em que atuam. São, enfim, figuradas como protagonistas heróis porque os diferentes processos discursivo-textuais de sua composição sobrelevaram algum aspecto de aprendizado com os mais velhos, os ancestrais, mesmo que esse aprendizado tenhaIhes imposto a morte. Entre as mudanças mais significativas pelas quais todos passamos, verificam-se a entrada na fase adulta e a morte, ritos sempre vivenciados à sombra da cultura a que os indivíduos se acham inseridos.

5 https://pt.wikipedia.org/wiki/Rito de passagem. Acesso em: 7 fev. 2021. 


\section{Referências}

COUTO, Mia. O dia em que explodiu o Mabata Bata. In: COUTO, Mia. Vozes anoitecidas. 4. ed. Lisboa: Caminho, p. 47-54, 1997.

COUTO, Mia. O embondeiro que sonhava pássaros. In: COUTO, Mia. Cada homem é uma raça. 11. ed. Lisboa: Caminho, p. 67-76, 2009. COUTO, Mia. Nas águas do tempo. In: COUTO, Mia. Estórias abensonhadas. 9. ed. Lisboa: Caminho, p. 13-18, 2009a.

COUTO, Mia. O pátio das sombras. Maputo: Escola Portuguesa de Moçambique - Centro de Ensino e Língua Portuguesa/ Fundação Contos para o Mundo, 2009b.

COUTO, Mia. O menino que escrevia versos. In: COUTO, Mia. O fio das missangas. São Paulo: Companhia das Letras, p. 131-134, 2009c.

REIS, Carlos. Dicionário de Estudos Narrativos. Coimbra: Almedina, 2018.

Flavio García é Professor associado da Universidade do Estado do Rio de Janeiro(UERJ).

Atua na Graduação em Letras e no PPGLetras, na área de Estudos de Literatura, nas especialidades de Literatura Portuguesa e de Teoria da Literatura e Literatura Comparada, com orientações de mestrados e doutorado e supervisões de pós-doutorado.

Iniciou em março de 2020, seu quarto pós-Doutorado, na área de Culturas e Literaturas Africanas de Língua Portuguesa da Faculdade de Letras da Universidade de Lisboa, intitulado "Figuração insólita de personagenstítulo em narrativas de Mia Couto admissíveis como literatura infantil e/ou juvenil?", sob a supervisão do Profa. Doutora Ana Mafalda Leite.

Lattes: $\underline{\text { https://lattes.cnpq.br/4242057381476599 }}$

ORCID iD: https://orcid.org/0000-0003-0761-8092 